\title{
An Empirical Analysis of the Causes of Air Crashes from a Transport Management Perspective
}

\author{
Mobolaji S. Stephens
}

Department of Transport Management Technology, Federal University of Technology, PMB 704 Akure, Nigeria

Wilfred I. Ukpere

Doi:10.5901/mjss.2014.v5n2p699

Department of Industrial Psychology \& People Management, Faculty of Management University of Johannesburg, South Africa Corresponding email: wiukpere@uj.ac.za or wilfredisiomaukpere@gmail.com

\begin{abstract}
Aviation has changed into high level of operations technically, administratively and even technologically. This has been made possible with the introduction and manufacture of larger and faster aircrafts that greatly incorporates advanced information management technologies. With increase in the volume of traffic and the demand for air transportation, comes the risk and increase in air crashes. Causes of air crashes have been studied by various researchers and bodies. What this studied did was to examine causes of air crashes from all over the world and analyze them based on the locations of accidents to determine the causes of accidents in different locations. It was observed that certain regions were recorded to have similar causes of accidents and some others were prone to certain causes of accidents. North America had more cases of air crashes over other regions but when compared with the volume of traffic in this region one will understand why they had many more crashes than others. They can be adjudged to be safer than some other regions such as Asia and Africa.
\end{abstract}

\section{Introduction}

The aircraft is a machine that can fly in the air either carrying passengers and or goods. However, the air transport industry is seen as an area of commerce where aircrafts are used to transport people, cargo and mail at the cheapest costs yet with the best safety measures employed. The movement is only complete when there is "safe arrival". An aviation incident is defined as an occurrence, other than an accident, associated with the operation of an aircraft that affects or could affect the safety of operations (AirSafe.com, 2009). The aviation industry is undoubtedly the safest, fastest and most comfortable mode of transportation. This is because safety and hospitality are too great features of the industry (Stephens, 2009). However, for one reason or another air crashes occur once in a while with severe consequences: loss if lives and valuable assets. When measured on a passenger-distance calculation, air travel is the safest form of transportation available: these figures are the ones mentioned by the air industry when quoting statistics on air safety. A typical statement is this one by the BBC: "UK airline operations are among the safest anywhere. When compared against all other modes of transport on a fatality per mile basis air transport is the safest - six times safer than traveling by car and twice as safe as rail." (Howstuffworks, 2012). However, should one measured by fatalities per person transported, buses are the safest form of transportation and the number of air travel fatalities per person is surpassed only by bicycles and motorcycles. This statistic is the one used by the insurance industry when calculating insurance rates for air travel. For every billion kilometers traveled, trains have a fatality rate 12 times larger than air travel, while automobiles have a fatality rate 62 times larger. On the other hand, for every billion journeys, buses are the safest form of transportation. By the last measure, air transportation is three times more dangerous than car transportation and almost 30 times more dangerous than bus (BBC News, 2000). After the crash of Gol Transportes Aéreos Flight 1907, Brazilian Air Force personnel recover the flight data recorder of the flight. A 2007 study found that passengers sitting at the back of a plane are $40 \%$ more likely to survive a crash than those sitting in the front, although this article also quotes Boeing, the FAA and a website on aircraft safety, all claiming that there is no safest seat. The article studied 20 crashes, not taking in account the developments in safety after those accidents (Noland, 2007). However, a flight data recorder is usually mounted in the aircraft's empennage (tail section), where it is more likely to survive a severe crash. Over $95 \%$ of people 
in U.S. plane crashes between 1983 and 2000 survived (Watt, 2007).

The frequency of occurrence of these air crashes is so low when compared with other modes of transport. This makes it mandatory for safety and security to be paramount in standard settings for airports, airlines, industry regulators and air users. Worldwide the safety and security of the aviation industry matters so much to governments as the bulk of air travellers is people that contributes greatly to wealth creation and owns the vast majority of world riches. This is particularly true in developing countries (Stephens et al, 2011) where less than five percent of the population uses air transport and these same set of people hold over eighty percent of the wealth in these economies. Stephens (2009) also forecasted the growth of the industry in Nigeria to be on a gradual rise as more people in Nigeria are able to afford air tickets due to the deregulation and increased competition. This trend is expected worldwide and this now brings to fore, again, the fear of air crashes as it is expected that developing economies and those emerging and rapidly adopting air transportation a mode of choice to travel (more domestically) as many of these nations may be ill-equipped to hand the expected surge in air travels and its safety measures demand.

Ability to know the causes of air crashes and disasters will go in a long way to prevent or reduce greatly their occurrence. The knowledge of causes in other countries' aviation industries is equally important to ascertain if there is any similarity in pattern/causes.

\section{Objective of the study}

The purpose of the study is to examine the causes of the numerous air crashes in the world since 1929 till 2011.

Sub-objectives

The followings are sub-objectives that drive this study:

i. To ascertain which regions are more prone to certain causes of air crashes.

ii. To examine the different causes of air crashes over time.

iii. To examine the different causes of air crashes on regional bases.

\section{Research Questions}

Air crashes take place once in a while and when it does, it affects every facet of the economy either directly or indirectly. This study will attempt to answer the following questions:

i. What are the different causes of air crashes?

ii. Which regions are more prone to certain causes of air crashes?

\section{Significance of the study}

No previous studies of air crashes had tried to relate air crashes happening in different areas of the world over time with those in other areas. The study highlights causes of accidents or air crashes and tied same to the locations of crashes or (origins and destinations) enabling a comparism along the lines of place and times of occurrence. This will expose the regional differences in the causes of air crashes. A safe aviation industry is a great boost to the world economy.

\section{Methodology}

\section{Design of the Study}

The research is designed to:
i. ascertain which regions are more prone to certain causes of air crashes;
ii. examine the different causes of air crashes over time;
iii. examine the different causes of air crashes on regional bases

\section{Area of Study}

The study covered the whole world, spanning a period between 1920 and 2011 considering air crashes occurrences.

\section{Method of Data Collection}

Research data were sourced from different international bodies in the aviation industry for records that covered 1920 to 2011. 


\section{Data Analytical Tools}

To analyze the data generated simple measures of dispersal were used and results were tabulated and displayed in simple illustrative format for easy understanding and comprehension.

\section{Limits and limitations}

The research work is limited to the availability of information as regards the records of air crashes.

\section{Causes of air accidents and records of air accidents}

Accidents records taking started about the 1920s and records. Many studies have been done on causes of air crashes. Clever (2009) in his study listed the following as the causes of air crashes:
i. Sabotage
ii. $\quad$ Bird strike
iii. Mechanical Failure
iv. Bad Weather
v. Fuel Starvation
vi. Hijacking
vii. Improper loading of aircraft
viii. Improper maintenance procedures
ix. Design flaw
$\mathrm{x} . \quad$ Lightening, and
xi. Pilot shoot by passenger

'Mechanical Failure' was used by Clever (2009) in his study but was replaced by 'Design Flaw' which was made to include 'Mechanical Failure'. 'Improper Maintenance Procedures' was dropped because. 'Pilot Incapacitation' was used in this study and it covered the killing of pilot by passenger.

in this study the causes of air crashes were limited to:
i. $\quad$ Lightening
ii. Design flaw
iii. Sabotage and Explosive Devices
iv. Fuel Starvation
v. Cargo Hold and Cabin Fire
vi. Hijacking
vii. Pilot Incapacitation
viii. $\quad$ Air Traffic Control (ATC) Errors
ix. Bird Strike
x. Unknown

Table 1: Air Accidents-Time based

\begin{tabular}{|c|c|c|c|}
\hline Year & Frequency & Cumulative Frequency & Percentage \\
\hline $1920-1939$ & 9 & & 4.306220096 \\
\hline $1940-1959$ & 39 & 48 & 18.66028708 \\
\hline $1960-1979$ & 70 & 118 & 33.49282297 \\
\hline $1980-1999$ & 65 & 183 & 31.10047847 \\
\hline $2000-$ till date & 26 & 209 & 12.44019139 \\
\hline
\end{tabular}

Source: Research work

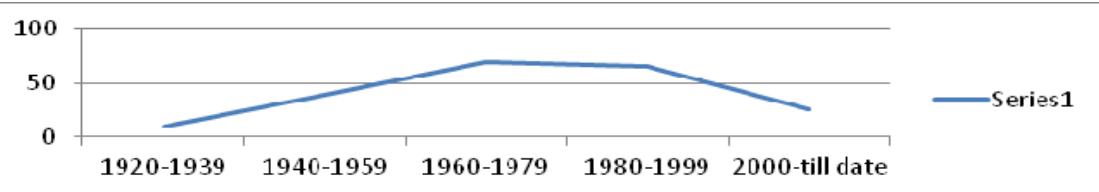

Figure 1: Air Accidents-Time based (series1 number of accidents).

Source: Research work 
The Geneva-based Aircraft Crashes Record Office (ACRO) compiles statistics on aviation accidents of aircraft capable of carrying more than six passengers, not including helicopters, balloons, or fighter airplanes. It should be noted that ACRO is not a government or official organization. The ACRO announced in 2008 that the year 2007 was the safest year in aviation since 1963p; in terms of number of accidents (ACRO, 2012).

There had been 136 accidents registered (compared to 164 in 2006), resulting in a total of 965 deaths (compared to 1,293 in 2006). Since then, both 2009 and 2010 saw fewer registered accidents, 122 and 130, respectively. 2004 was the year with the lowest number of fatalities since the end of World War II, with 771 deaths. The year with most fatalities was 2001, with 4,140 deaths. Those numbers may be less than the total aircraft accidents fatalities as ACRO only considers accidents in which the aircraft has suffered such damage that it is removed from service

Table 2: Air accidents and deaths

\begin{tabular}{|c|c|c|}
\hline Year & death & number of accidents \\
\hline 1999 & 1138 & 211 \\
\hline 2000 & 1582 & 189 \\
\hline 2001 & 4140 & 200 \\
\hline 2002 & 1413 & 185 \\
\hline 2003 & 1230 & 199 \\
\hline 2004 & 771 & 172 \\
\hline 2005 & 1459 & 185 \\
\hline 2006 & 1294 & 166 \\
\hline 2007 & 971 & 147 \\
\hline 2008 & 884 & 156 \\
\hline 2009 & 1103 & 122 \\
\hline 2010 & 1115 & 130 \\
\hline 2011 & 828 & 117 \\
\hline
\end{tabular}

Source: ACRO, 2012

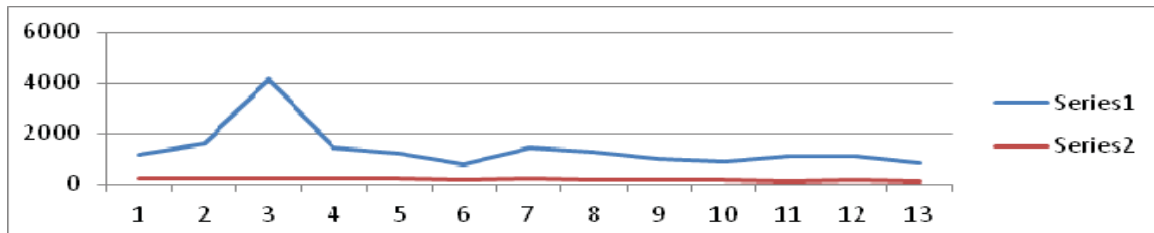

Figure 2: Air Accidents-Time based (Note Series 1= number of deaths; Series 2= number of crashes). Source: ACRO, 2012

Table 3: causes of air crashes in 1920 - 1939

\begin{tabular}{|l|r|r|}
\hline $1920-1939$ & Frequency & \\
\hline Cause & 2 & 20 \\
\hline Lightening & 1 & 10 \\
\hline Design Flaw & 3 & 30 \\
\hline Sabotage / Explosive Device & 4 & 40 \\
\hline Fuel Starvation & 0 & 0 \\
\hline Cargo Hold/Cabin Fire & 0 & 0 \\
\hline Hijacking (Resulting in Fatalities) & 0 & 0 \\
\hline Pilot Incapacitation & 0 & 0 \\
\hline Air Traffic Control Errors & 0 & 0 \\
\hline Bird Strikes & 0 & 0 \\
\hline Unknown & 10 & 100 \\
\hline Total & & \\
\hline
\end{tabular}

Source: Research work 


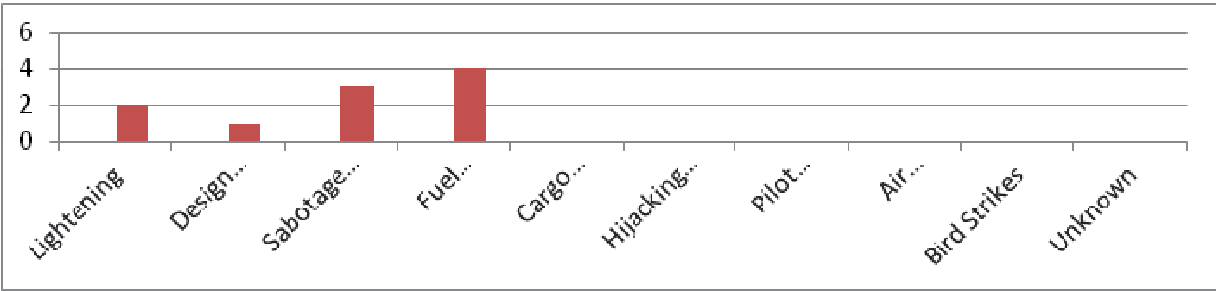

Figure 3: Causes of air crashes in 1920 - 1939. Source: Research work

An examination of causes of air crashes over the years showed that during the formative years, fuel starvation, design flaws and lightening were major reasons for crashes. Then, the manufacturing of aircrafts and technologies involved were not as perfected as they have turned out to be now. Pilots then can underestimate the volume of fuel needed for flights. Also the materials used for making the outer casing of the fuselages were not of the same technology as we have them today (see tables 3 and 4 and the corresponding figures).

Table 4: Causes of air crashes in $1940-1959$

\begin{tabular}{|l|r|r|}
\hline 1940-1959 & \multicolumn{2}{l|}{} \\
\hline Cause & Frequency & Percentage \\
\hline Lightening & 3 & 7.692307692 \\
\hline Design Flaw & 8 & 20.51282051 \\
\hline Sabotage / Explosive Device & 9 & 23.07692308 \\
\hline Fuel Starvation & 12 & 30.76923077 \\
\hline Cargo Hold/Cabin Fire & 2 & 5.128205128 \\
\hline Hijacking (Resulting in Fatalities) & 2 & 5.128205128 \\
\hline Pilot Incapacitation & 2 & 5.128205128 \\
\hline Air Traffic Control Errors & 1 & 2.564102564 \\
\hline Bird Strikes & 0 & 0 \\
\hline Unknown & 0 & 0 \\
\hline Total & 39 & 100 \\
\hline
\end{tabular}

Source: Research work

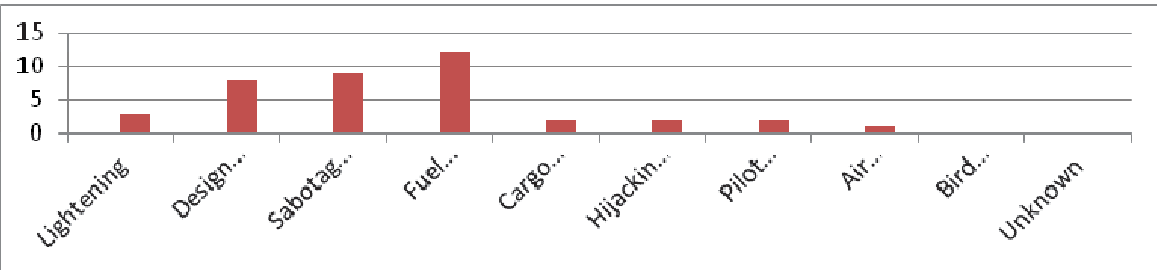

Figure 4: Causes of air crashes in 1940 - 1959. Source: Research work

With time the focal cause of air crashes moved from what it were in the formative era of the industry to human-based causes that were intentional whether for political reasons or some other courses that is extraneous to the industry. These included sabotage/explosive devices and hijacking that results in fatalities. There were those that were caused by human too but non-intentional like ATC errors pilot incapacitation. Table 5 (and the corresponding figure) depicts this era.

The growth of the industry greatly increased after the crisis of the 1970s occasioned by unrest and wars in the Mideast that led to increased fuel cost. The growth could significantly attributed to (though other factors were involved) the introduction of longer distance capable jumbo jets which also offers increase capacity. 
This technological advancement was significant in the industry and led to the growth of some airports to becoming major global players as hubs and transit points. Sabotage, fuel starvation, hijacking were still dominant causes of air crashes in this period (see table 6 and the corresponding figure). One would have expected fuel starvation to drop as a major cause of disasters but the lure of the new jumbo jets and their ability to make longer trips led to errors in fuel estimation for long distance flights.

Table 5: Causes of air crashes in $1960-1979$

\begin{tabular}{|l|c|c|}
\hline $1960-1979$ & Frequency & Percentage \\
\hline Cause & 7 & 10 \\
\hline Lightening & 3 & 4.285714286 \\
\hline Design Flaw & 20 & 28.57142857 \\
\hline Sabotage / Explosive Device & 8 & 11.42857143 \\
\hline Fuel Starvation & 8 & 11.42857143 \\
\hline Cargo Hold/Cabin Fire & 9 & 12.85714286 \\
\hline Hijacking (Resulting in Fatalities) & 6 & 8.571428571 \\
\hline Pilot Incapacitation & 7 & 10 \\
\hline Air Traffic Control Errors & 2 & 2.857142857 \\
\hline Bird Strikes & 0 & 0 \\
\hline Unknown & 70 & 100 \\
\hline Total & & \\
\hline
\end{tabular}

Source: Research work

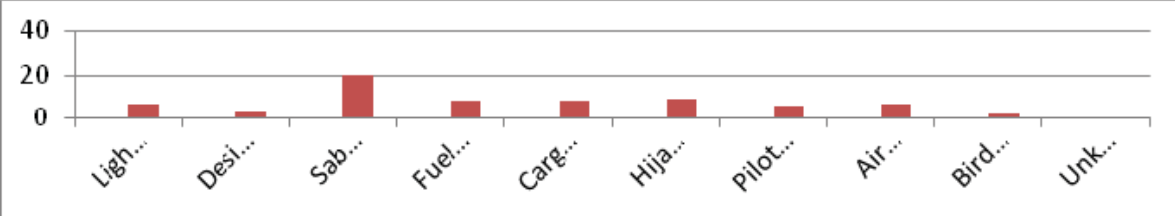

Figure 5: Causes of air crashes in 1960 - 1979. Source: Research work

Hijacking was still prominent because even though the wars were over, the disputes and issues that led to the wars were not resolved. ATC errors increased with time (see tables 5 and 6 and the corresponding figures) and this could not be unexpected as increased traffic requires improvement traffic management, technologies and understanding.

Table 6: Causes of air crashes in $1980-1999$

\begin{tabular}{|l|c|c|}
\hline $1980-1999$ & \multicolumn{2}{|c|}{} \\
\hline Cause & Frequency & Percentage \\
\hline Lightening & 2 & 3.076923077 \\
\hline Design Flaw & 5 & 7.692307692 \\
\hline Sabotage / Explosive Device & 14 & 21.53846154 \\
\hline Fuel Starvation & 13 & 20 \\
\hline Cargo Hold/Cabin Fire & 9 & 13.84615385 \\
\hline Hijacking (Resulting in Fatalities) & 13 & 20 \\
\hline Pilot Incapacitation & 2 & 3.076923077 \\
\hline Air Traffic Control Errors & 4 & 6.153846154 \\
\hline Bird Strikes & 3 & 4.615384615 \\
\hline Unknown & 0 & 0 \\
\hline Total & 65 & 100 \\
\hline
\end{tabular}

Source: Research work 
Design flaw was responsible for $7.69 \%$ of causes of air crashes between 1980 and 1999 . Many crashes during this period were mid-air collision involving two aircrafts and malfunctioning of devices in the aircrafts. Flaws were seen in the inability of the aircrafts on course for head-on collision to communicate with each other particularly when in auto-pilot mode and the non-standardization of measuring devices and calibration in all aircraft. And since then aircrafts made since mid-1990s now come ability to communicate with each other using a binary system to avoid head-on collision. In addition, calibrations and units of measurements are now standardized.

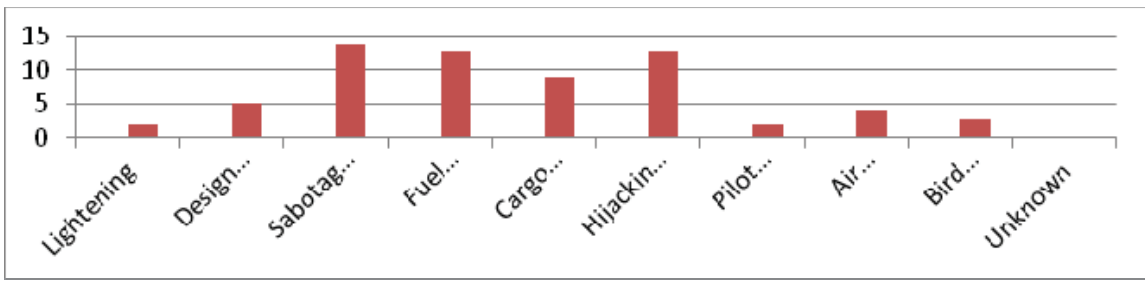

Figure 6: Causes of air crashes in 1980 - 1999. Source: Research work

The collapse of the Soviet Union in the late 1980s brought about the opening up of many new routes and destination for more airlines. This greatly increased air traffic and were further made possible by rush to leave for greener pastures; rush to enter new markets for investments and new opportunities and the reformation of market structures and economies.

The Americans travel more by air than other nationals and it should not be unexpected if the North America had the highest record of air crashes since 1929 till 2011 (see tables 8 and the corresponding figure).

Table 7: Causes of air crashes in 2000 - till date

\begin{tabular}{|l|c|c|}
\hline 2000-till date & \multicolumn{2}{|c|}{} \\
\hline Cause & Frequency & Percentage \\
\hline Lightening & 0 & 0 \\
\hline Design Flaw & 3 & 11.53846154 \\
\hline Sabotage / Explosive Device & 6 & 23.07692308 \\
\hline Fuel Starvation & 0 & 0 \\
\hline Cargo Hold/Cabin Fire & 6 & 23.07692308 \\
\hline Hijacking (Resulting in Fatalities) & 2 & 7.692307692 \\
\hline Pilot Incapacitation & 1 & 3.846153846 \\
\hline Air Traffic Control Errors & 2 & 7.692307692 \\
\hline Bird Strikes & 3 & 11.53846154 \\
\hline Unknown & 0 & 0 \\
\hline Total & 26 & 100 \\
\hline
\end{tabular}

Source: Research work

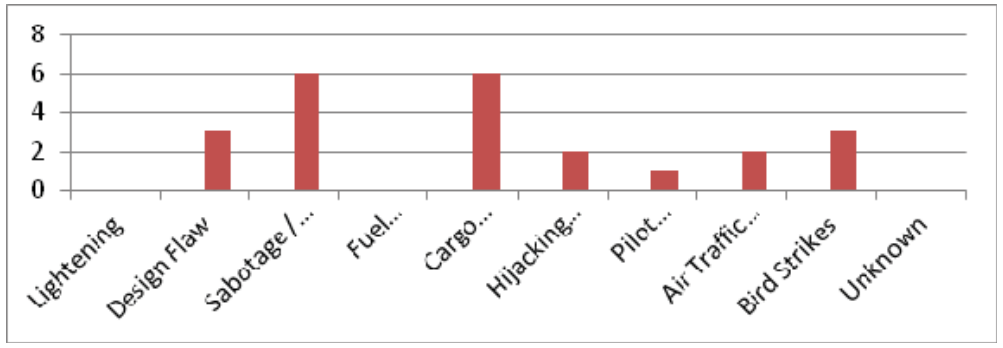

Figure 7: Causes of air crashes in 2000 - till date. Source: Research work 
Table 8: Air crash distribution (1929-2011)

\begin{tabular}{|l|r|r|r|}
\hline Place & \multicolumn{2}{|c|}{ Frequency } & \multicolumn{2}{l|}{ Cumulative Frequency } & Percentage \\
\hline North America & 67 & & 32.05741627 \\
\hline Europe & 55 & 122 & 26.31578947 \\
\hline Asia & 42 & 164 & 20.09569378 \\
\hline Africa & 23 & 187 & 11.00478469 \\
\hline South America & 19 & 206 & 9.090909091 \\
\hline Autralia/Oceania & 3 & 209 & 1.435406699 \\
\hline
\end{tabular}

Source: Research work

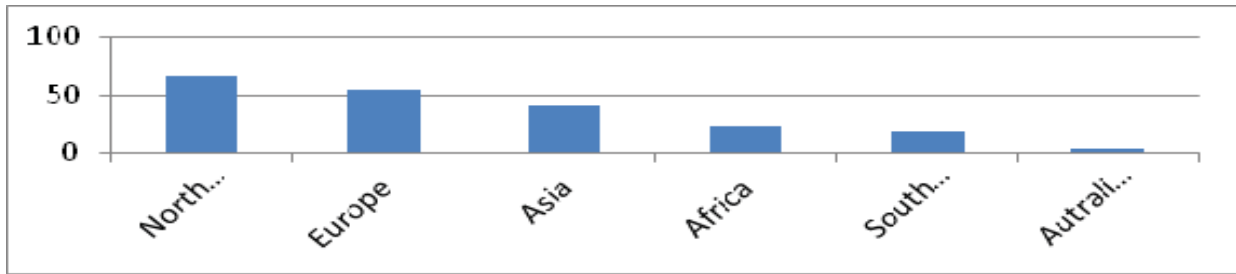

Figure 8: Air crash distribution (1929-2011). Source: Research work

However, that trend may be changing with the increase in affluence and disposable income being witnessed in Asia and in China in particular. China will have more flights with time than any other nation but their poorly developed aviation industry, like most their economy at large, which geared towards rapid expansion and poor safety and economic regulations could mean more air crashes in the Asia.

Table 9: Air crash distribution (caused by lightening) (1929-2011).

\begin{tabular}{|l|r|r|r|}
\hline Place & Frequency & Cumulative Frequency & Percentage \\
\hline Europe & 9 & & 52.94117647 \\
\hline North America & 3 & 12 & 17.64705882 \\
\hline South America & 2 & 14 & 11.76470588 \\
\hline Asia & 2 & 16 & 11.76470588 \\
\hline Africa & 1 & 17 & 5.882352941 \\
\hline Australia/ Oceania & 0 & 17 & 0 \\
\hline
\end{tabular}

Source: Research work

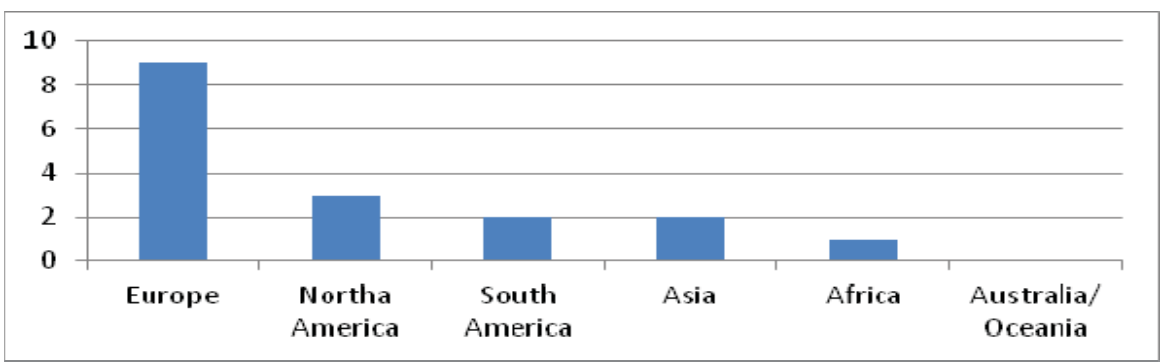

Figure 9: Air crash distribution caused by lightening (1929-2011). Source: Research work 
African being almost evenly divided by the equator and within the tropics would have been expected to have more air crashes caused by lightening but that was not the case because the level of air transport traffic and activities in this region is small but growing and not up to what is obtainable in other regions. Europe recorded the most for this cause followed by North America (see table 9 and figure 9). Worthy of note is the fact that air crashes caused by lightening has greatly reduced and since the year 2000 till time of this research no air crash was caused by lightening.

Table 10: Air crash distribution (caused by design flaws) (1929-2011).

\begin{tabular}{|l|r|l|r|}
\hline Place & Frequency & Cumulative Frequency & \multicolumn{1}{l|}{ Percentage } \\
\hline North America & 10 & & 58.8235294 \\
\hline Europe & 5 & 15 & 29.4117647 \\
\hline Africa & 1 & 16 & 5.88235294 \\
\hline Asia & 1 & 17 & 5.88235294 \\
\hline South America & 0 & 17 & 0 \\
\hline Australia/ Oceania & 0 & 17 & 0 \\
\hline & 17 & & 100 \\
\hline
\end{tabular}

Source: Research work

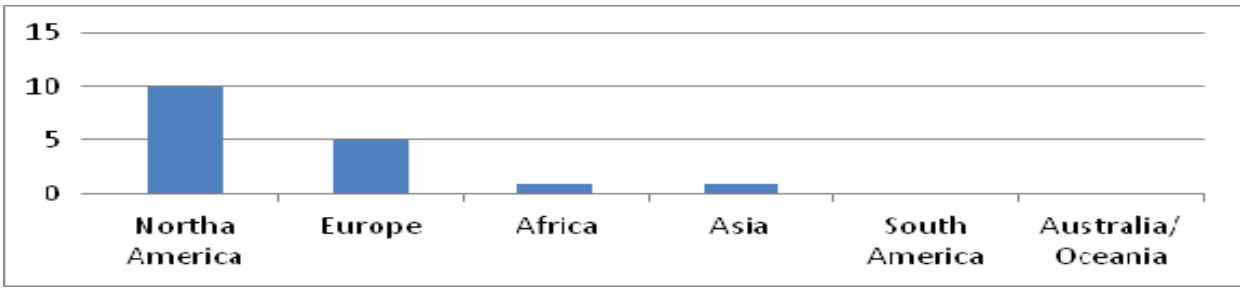

Figure 10: Air crash distribution caused by design flaws (1929-2011). Source: Research work

North America still led in the number of air crashes caused by design flaws. This could also be attributed to the large patronage and use of air transportation in this region. However, air transportation is highly developed in the Australia/Oceania yet there is no record of crashes caused by design flaws (table 10 and figure 10)

Table 11: Air crash distribution (caused by sabotage/explosive device) (1929-2011).

\begin{tabular}{|l|r|r|r|}
\hline Place & Frequency & Cumulative Frequency & \multicolumn{1}{l|}{ Percentage } \\
\hline Europe & 13 & & 27.08333333 \\
\hline Asia & 13 & 26 & 27.08333333 \\
\hline North America & 11 & 37 & 22.91666667 \\
\hline South America & 7 & 44 & 14.58333333 \\
\hline Africa & 4 & 48 & 8.333333333 \\
\hline Australia/ Oceania & 0 & 48 & 0 \\
\hline & 48 & & 100 \\
\hline
\end{tabular}

Source: Research work

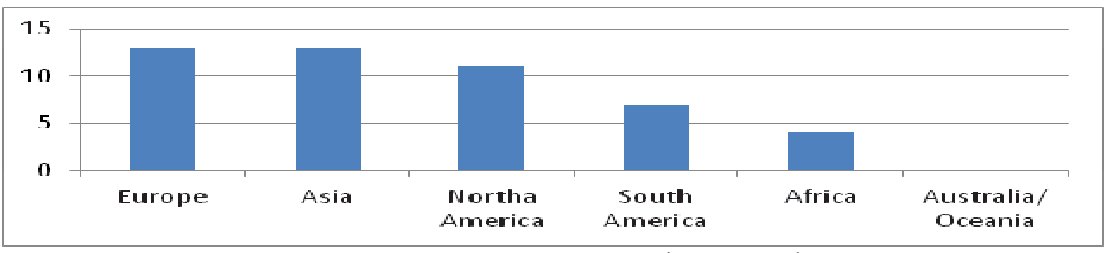

Figure 11: Air crash distribution caused by sabotage/explosive device (1929-2011).

Source: Research work 
The Israeli/Palestinian dispute over for land and the tension caused by the various political differences in the in the Middle-East made the western states and their aircrafts easy targets for sabotage/explosion. That is why Europe, Asia and North America led in the air crashes caused by sabotage/explosion (see table11 and figure 11). Europe had the most share of the world partly due to its close proximity to the "hot spot": Middle-East and agitations for self-determinations in some states in the region like Basque in the South and north of France and Spain respectively; the IRA in Northern Ireland and the Kurdish rebels in the eastern Turkey.

Table 12: Air crash distribution (caused by fuel starvation) (1929-2011).

\begin{tabular}{|l|c|c|c|}
\hline Place & Frequency & Cumulative Frequency & Percentage \\
\hline North America & 17 & & 39.53488372 \\
\hline Asia & 9 & 26 & 20.93023256 \\
\hline Europe & 8 & 34 & 18.60465116 \\
\hline Africa & 5 & 39 & 11.62790698 \\
\hline South America & 3 & 42 & 6.976744186 \\
\hline Australia/ Oceania & 1 & 43 & 2.325581395 \\
\hline & 43 & & 100 \\
\hline
\end{tabular}

Source: Research work

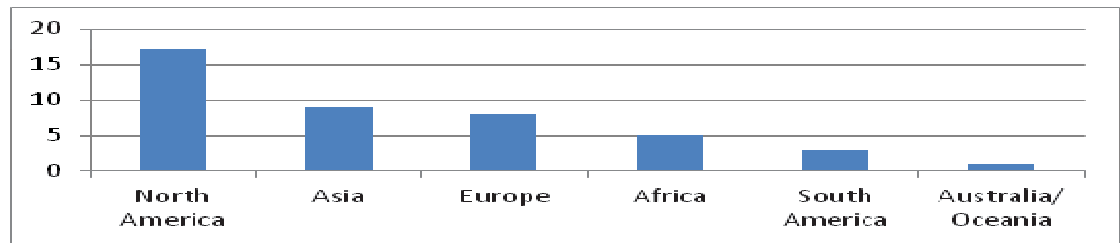

Figure 12: Air crash distribution caused by fuel starvation (1929-2011).

Source: Research work

Starvation can be expected for long distance trips/flights where pilots would believer the fuel they carry can see them through to the next point of call, whereas the fuel might not be enough. North America had the highest level of share of crashes caused by fuel starvation most of which were recorded in the infancy stage of the aviation industry (see tables 3 and 12 and figure 12). Asia came second in this aspect and theirs too could be attributed to high levels recorded during infancy of the industry and miscalculations in the later stages.

Table 13: Air crash distribution (caused by cargo hold/cabin fire) (1929-2011).

\begin{tabular}{|l|r|r|r|}
\hline Place & Frequency & Cumulative Frequency & Percentage \\
\hline North America & 6 & & 31.57894737 \\
\hline Europe & 6 & 12 & 31.57894737 \\
\hline Asia & 3 & 15 & 15.78947368 \\
\hline South America & 2 & 17 & 10.52631579 \\
\hline Africa & 2 & 19 & 10.52631579 \\
\hline Australia/ Oceania & 0 & 19 & 0 \\
\hline & 19 & & 100 \\
\hline
\end{tabular}

Source: Research work

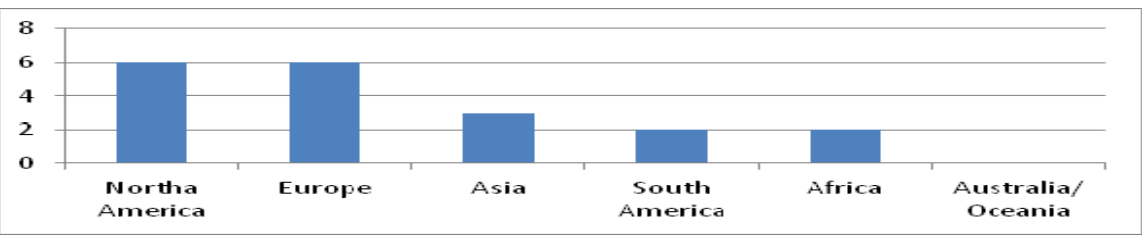

Figure 13: Air crash distribution caused by cargo hold/cabin fire (1929-2011).

Source: Research work 
North America and Europe still had the highest share of crashes caused by cargo hold/cabin fire (table 13 and figure 13). This is basically due to the volume of air traffic in these regions. Asia, particularly the Far East might overtake America due to the strong growth of the industry in this region most especially is the safety regulatory standards in the region are not improved.

Table 14: Air crash distribution (caused by hijacking) (1929-2011).

\begin{tabular}{|l|r|r|r|}
\hline Place & Frequency & Cumulative Frequency & Percentage \\
\hline Asia & 12 & & 40 \\
\hline North America & 7 & 19 & 23.33333333 \\
\hline Africa & 5 & 24 & 16.66666667 \\
\hline Europe & 3 & 27 & 10 \\
\hline South America & 2 & 29 & 6.666666667 \\
\hline Australia/ Oceania & 1 & 30 & 3.333333333 \\
\hline & 30 & & 100 \\
\hline
\end{tabular}

Source: Research work

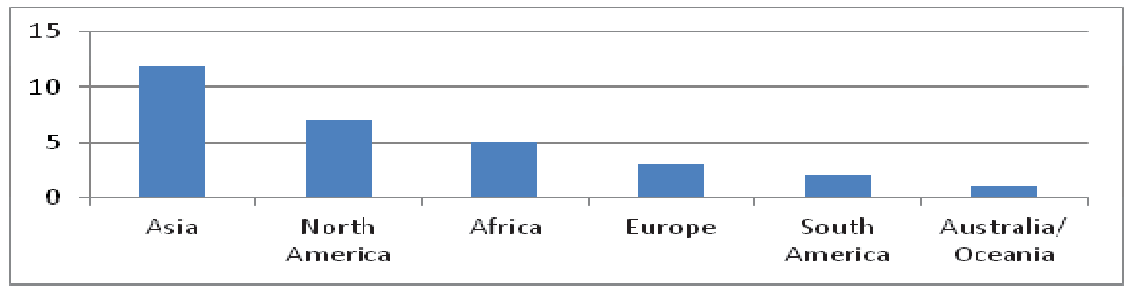

Figure 14: Air crash distribution caused by hijacking (1929-2011).

Source: Research work

Asia led in crashes caused by hijacking (table 4 and figure 14). This might not be unconnected with the political situations in the Middle-East, the struggle self-determination in Kashmir and Sri Lanka in South Asia; Southern Philippines and East Timor. Africa notable came third and this could be linked to the struggles in the Middle-East too.

Table 15: Air crash distribution (caused by pilot incapacitation) (1929-2011).

\begin{tabular}{|l|r|l|r|}
\hline Place & Frequency & Cumulative Frequency & \multicolumn{1}{l|}{ Percentage } \\
\hline North America & 4 & & 33.33333333 \\
\hline Europe & 4 & 8 & 33.33333333 \\
\hline South America & 1 & 9 & 8.333333333 \\
\hline Africa & 1 & 10 & 8.333333333 \\
\hline Asia & 1 & 11 & 8.333333333 \\
\hline Australia/ Oceania & 1 & 12 & 8.333333333 \\
\hline & 12 & & 100 \\
\hline
\end{tabular}

Source: Research work

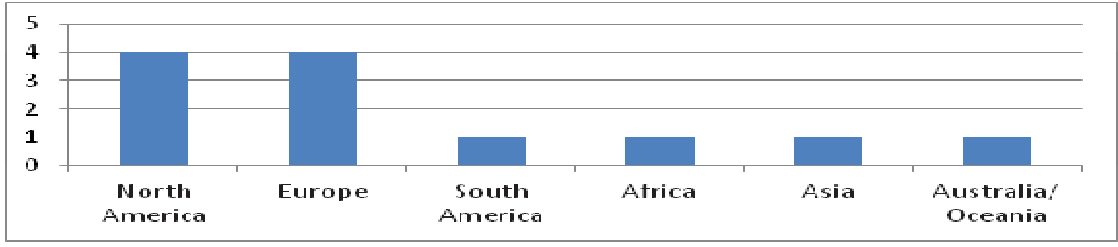

Figure 15: Air crash distribution caused by pilot incapacitation (1929-2011).

Source: Research work 
Pilot incapacitation and ATC errors as causes of air crashes showed North America and Europe to have most shares of these causes (tables 15 and 16, figures 15 and 16). This could be purely due to the high volume of traffic in these regions. African share was however seen to be rather high for ATC which could be tied to the rapidly growth of the industry in the region. The region need to keep training its operatives to meet the latest and best practices as obtainable in regions with best safety records.

Table 16: Air crash distribution (caused by ATC error) (1929-2011).

\begin{tabular}{|l|r|r|r|}
\hline Place & Frequency & Cumulative Frequency & Percentage \\
\hline North America & 5 & & 38.46153846 \\
\hline Europe & 3 & 8 & 23.07692308 \\
\hline Africa & 1 & 9 & 7.692307692 \\
\hline Asia & 1 & 10 & 7.692307692 \\
\hline South America & 0 & 10 & 0 \\
\hline Australial Oceania & 0 & 10 & 0 \\
\hline & 13 & & 100 \\
\hline
\end{tabular}

\section{Source: Research work}

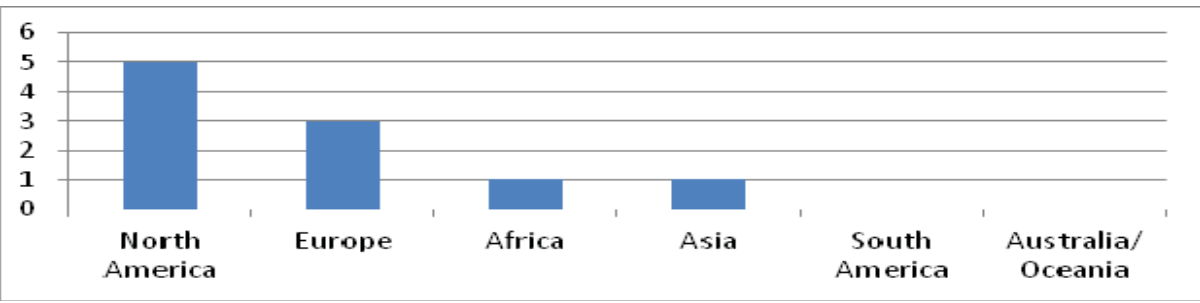

Figure 16: Air crash distribution caused by ATC error (1929-2011).

Source: Research work

North America and Africa led in crashes caused by bird strike (table 17 and figure 17). This cause of air crashes was seen to be lesser at the infancy stage of the industry but steadily increased with time (see tables 3-7)

Table 17: Air crash distribution (caused by bird strike) (1929-2011).

\begin{tabular}{|l|r|l|r|}
\hline Place & Frequency & Cumulative Frequency & Percentage \\
\hline North America & 4 & & 57.14285714 \\
\hline Africa & 2 & 6 & 28.57142857 \\
\hline South America & 1 & 7 & 14.28571429 \\
\hline Europe & 0 & 7 & 0 \\
\hline Asia & 0 & 7 & 0 \\
\hline Australia/ Oceania & 0 & 7 & 0 \\
\hline
\end{tabular}

Source: Research work

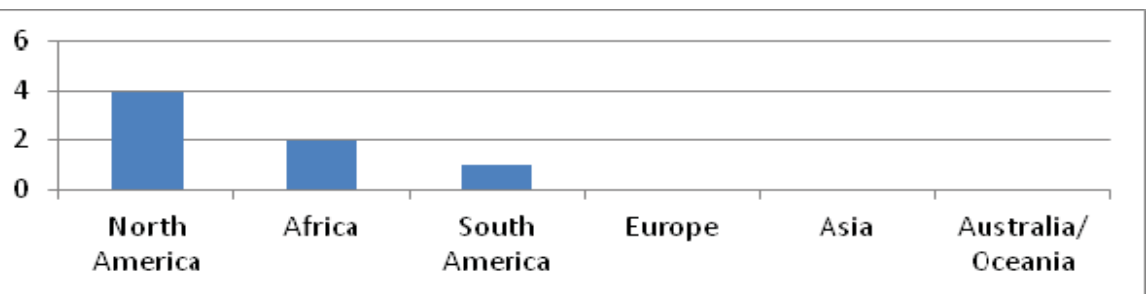

Figure 17: Air crash distribution caused by bird strike (1929-2011).Source: Research work 
Migratory birds abounds in all these regions and results for Africa particularly placed it in stronger position as it lies in the path of flights of migratory birds moving from the temperate regions in the northern and southern hemispheres.

\section{Conclusion}

Being faced with increased demand for air transportation the reduction of the air crashes and accident is very important. However, who will foot the bill? The US general Accounting Office, GAO (1997) called for more government-industry partnerships. Government, the industry and the traveling public would likely share in these costs reduction.

\section{References}

Air Safe (2009), "Definitions of Key Terms Used by AirSafe.com". AirSafe.com. 23 January 2009. Retrieved 22 July 2012 from http://www.airsafe.com/events/define.htm.

How stuffworks? (2012), "How Airplanes Work". Retrieved 9 May 2012 from http://science.howstuffworks.com/transportflights/modern lairplanes11htm.

BBC News. 8 May 2000, "Flying still the safest form of travel". Retrieved 2010-01-01 fromhttp://bbc.co.uk/2/hi/uk news/736582

Clever, Gogo (2009), Air Transport Safety, a degree thesis submitted to the department of Transport Management Technology, federal University of technology, Owerri

US General Accounting Office (1997), Aviation Safety And Security, Challenges to Implementing the Recommendations of the White House Commission on Aviation Safety and Security, statement by Gerald L. Dillingham, Associate Director, Transportation Issues, Resources, Community, and Economic Development Division

Number Watch (2001), "The risks of travel". Retrieved 26 January 2012 from http://numberwatch.co.uk/risks_of_travel.htm.

David Noland (2007), "Safest Seat on a Plane: PM Investigates How to Survive a Crash". Popular Mechanics. Retrieved on 8 August 2012 from http://www.popuplarmechanics.com/science/air_space/4219452.html?safe

Watt, Nick (17 January 2007). "Staying Alive During a Plane Crash". ABC News. Archived from the original on 29 October 2009. Retrieved 2 May 2012 from http://abcnews.go.com/nightline/story?id=2619382\&page=1.

ACRO (2012), ACRO Presentation. ACRO. Retrieved 12 May 2012 from http://www.baaa-acro.com/presentationacro.htm

"Transport Accident Investigation Commission". TAIC. Retrieved 9 May 2012.

GI Korea. "Arrow Air Flight 1285: Canada's Worst Aviation Disaster Remains an American Mystery". Retrieved 7 May 2012.

The Learning Network. 21-1988-pan-am-flight-103-crashes-over-lockerbie-scotland/ "December 21, 1988: Pan Am Flight 103 Crashes Over Lockerbie, Scotland". Retrieved 7 May 2012. 
E-ISSN 2039-2117

ISSN 2039-9340
Mediterranean Journal of Social Sciences MCSER Publishing, Rome-Italy
Vol 5 No 2 January 2014 